УДК 338.242

JEL classification: M11, Q40, Q42

ORCID ID: 0000-0001-9791-3612

Національний технічний університет Украйни

«Київський політехнічний інститут імені Ігоря Сікорського»

Артеменко Л.П.

канд. економ. наук, дочент

ORCID ID: 0000-0002-8585-0252

Національний технічний університет України

«Київський політехнічний інститут імені Ігоря Сікорського»

\title{
СТРАТЕГІЧНЕ УПРАВЛІННЯ РЕСУРСОЗБЕРЕЖЕННЯМ ПІДПРИСМСТВА В УМОВАХ ЕНЕРГЕТИЧНИХ ОБМЕЖЕНЬ
}

\section{СТРАТЕГИЧЕСКОЕ УПРАВЛЕНИЕ РЕСУРСОСБЕРЕЖЕНИЕМ ПРЕДПРИЯТИЯ В УСЛОВИЯХ ЭНЕРГЕТИЧЕСКИХ ОГРАНИЧЕНИЙ}

\section{STRATEGIC MANAGEMENT OF RESOURCE EFFICIENCY OF THE ENTERPRISE IN THE CONDITIONS OF ENERGY CONSTRAINTS}

У статті досліджено теоретичні аспекти поняття «ресурсозбереження», виділено основні принщипи щьодо формування системи управління ресурсозбереженням на підприємстві, проаналізовано ефект від ресурсозбереження для кожного з учасників виробничого прочесу, обтрунтовано труднощуі очінки економічних ефектів від впровадження ресурсозберігаючих заходів. Розглянуто діяльність пивоварного заводу ПАТ «Оболонь» в умовах енергетичних обмежень. Окреслено напрямки виробництва, в яких можлива економія ресурсів. Світовий досвід щ⿻одо реалізачії ресурсозберігаючих технологій розкрито в статті. Акиентовано увагу на головних стратегіях ресурсозбереження підприємств, а саме це зниження використання води, викидів в атмосферу, рециклінг вторинних ресурсів та активна реалізація альтернативних джерел енергії. Представлено результати розрахунку вартості проекту зі встановлення передової системи рекуперації теплової енергії Мусотіzеr із врахуванням високого рівня інфляції внаслідок нестабільного зовнішнього середовища.

Ключові слова: стратегічне управління ресурсозбереженням, енергозбереження, рекуперація теплової енергії, енергетичні обмеження, використання вторинних ресурсів.

В статье исследованы теоретические аспекты понятия «ресурсосбережение», выделены основные принципы формирования системы управления ресурсосбережением на предприятии, проанализирован эффект от ресурсосбережения для каждого из участников производственного прочесса, обоснованны трудности оченки экономических эффектов от внедрения ресурсосберегающих технологий. Рассмотрена деятельность пивоваренного завода ПАО «Оболонь» в условиях энергетических ограничений. Обозначень направления производства, в которых возможна экономия ресурсов. Мировой опьт по реализащии ресурсосберегающих технологий раскрыто в статье. Акиентировано внимание на главных стратегиях ресурсосбережения предприятий, а именно это снижение использования воды, выбросов в атмосферу, рециклинг вторичных ресурсов и активная реализачия альтернативных источников энергии. Представлены результаты расчета 
стоимости проекта по установке передовой системы рекуперации тепловой энергии Мусотіzег с учетом высокого уровня инфляции вследствие нестабильной внешней среды.

Ключевые слова: стратегическое управление ресурсосбережением, энергосбережение, рекуперация тепловой энергии, энергетические ограничения, использование вторичных ресурсов.

The theoretical aspects of the concept of «resource saving», the basic principles of the systems of resource-saving management at the enterprise, the effect of the resource-saving for each of the participants involved in the production process, the difficulties in the assessment of economic effects of the introduction of resource-saving activities are provided in the article. It was reviewed the work of the brewery PJSC «Obolon» in the conditions of energy constraints and provided areas of production in which resource-saving is possible. World experience on the implementation of resource-saving technologies is disclosed in the article. The attention is focused on the main strategies of resource saving enterprises, namely, the reduction of water use, emissions into the atmosphere, recycling of secondary resources and the active implementation of alternative energy sources. There were also provided results of the cost calculation of the project to install advanced recovery systems thermal energy Mycomizer with regard to the high level of inflation due to a changeable external environment.

Keywords: strategic management of resource efficiency, energy-saving, recuperation of heat energy, energy constraints, reuse of recoverable resources.

Вступ. Нестабільність ринкової економіки та стрімке зростання вартості енергоносіїв обумовлює необхідність пошуку і впровадження передових ресурсозберігаючих технологій, які б дозволили не тільки зменшити вплив на оточуючий світ, але значно економити кошти компаній. 3 огляду на це, наукова робота характеризується актуальністю та спрямована на розроблення стратегії ресурсозбереження, що забезпечить підвищення ефективності виробничого процесу підприємства.

Наукова новизна дослідження полягає у систематизації теоретикоприкладних засад реалізації політики ресурсозбереження на підприємстві та подальшому розвитку стратегічного управління ресурсозбереженням в харчовій промисловості в умовах енергетичних обмежень при використанні вторинних ресурсів.

Дослідженням проблем стратегічного управління ресурсозбереженням у ринкових умовах господарювання займались такі вчені як Д.В. Зеркалов [1], Л.С. Довгань [2], І.М. Сотник [3], Н.В. Мельничук [4], В.І. Куцик, М.В. Олійник [5], I.О. Ляшенко [8] та інші. Проте на сьогодні невирішеними залишається ще достатньо питань, які стосуються розробки і впровадження енергозберігаючих технологій на українських промислових підприємствах.

Постановка завдання. Метою роботи $є$ розробка напрямів покращення стратегічного управління ресурсозбереженням підприємства в умовах енергетичних обмежень на прикладі діяльності підприємства ПАТ «Оболонь». Досягнення поставленої мети потребує вирішення таких завдань: 
- розкрити сутність та основні проблеми ресурсозбереження;

- оцінити стан та можливості покращення стратегічного управління ресурсозбереженням підприємства;

- обгрунтувати доцільність вибору та ефективність реалізації стратегії ресурсозбереження ПАТ «Оболонь».

Методологія. Для вирішення поставлених завдань у процесі дослідження було використано такі методи:аналітичний, порівняльний, описовий, графічний, табличний i метод динаміки явищ. Теоретичною основою дослідження є роботи провідних зарубіжних та вітчизняних вчених, що присвячені питанням розробки $\mathrm{i}$ впровадження стратегії ресурсозбереження на промислових підприємствах.

Результати дослідження. Проблема ресурсозбереження, залишаючись однією 3 найважливіших в усіх країнах, стає пріоритетною і в нашій державі. Саме поняття «ресурсозбереження» $є$ багатоаспектним і може проявлятись в багатьох явищах; з боку суспільно-необхідної праці як зменшення витрат на випуск продукції, зростання норми прибутку, поліпшення стану навколишнього природнього середовища, а з боку підприємства - у вигляді енергозбереження, матеріалозбереження, працезбереження і т.д. [5].

Ресурсозбереження $є$ одним із ключових напрямів в політиці управління сучасними підприємствами. Розглянувши та проаналізувавши різні підходи до визначення економічної сутності категорії «ресурсозбереження», можна зробити висновок, що більшість науковців визначає ресурсозбереження як комплекс технічних, економічних, організаційних заходів, спрямованих на раціональне використання ресурсів та забезпечення зростаючих потреб у них головним чином за рахунок економії [6].

Враховуючи сучасні тенденції економічного розвитку, ресурсозбереження - це такий метод господарювання, за якого раціональне використання усіх ресурсів підприємства обов'язково супроводжується впровадженням ресурсозберігаючих технологій та прийняттям ефективних управлінських рішень стосовно них [7].

Стратегічне управління ресурсозбереженням у виробництві є процесом, спрямованим на досягнення оптимального рівня витрат ресурсів. Сучасна ситуація в Україні зумовлює не тільки доцільність, але і необхідність іі просування до ресурсозберігаючого типу відтворення, який вимагає підвищення ефективності використання всіх без винятку видів ресурсів: матеріальних, енергетичних, техніко-технологічних, фінансових, інформаційних, трудових, інтелектуальних. В даному контексті ресурсозбереження $\epsilon$ важливим інструментом підвищення ефективності виробництва і збільшення прибутку [7].

Управління ресурсозбереженням повинно представляти собою комплексний процес, пов'язаний 3 управлінням якістю продукції, 
транспортуванням та зберіганням, а також з екологією, оскільки джерелом усіх ресурсів, у тому числі матеріальних, $\epsilon$ природа. Фрагментарне або точкове впровадження ресурсозбереження на підприємстві не може забезпечити стале отримання позитивних ефектів. Діяльність підприємства має постійно функціонувати на засадах ресурсозбереження та, відповідно, потребує належного управління і формування системи ресурсозбереження. У більшості вітчизняних підприємств система ресурсозбереження відсутня або обмежується економним використанням ресурсів [8].

У зв'язку з цим можна виділити основні принципи щодо формування системи управління ресурсозбереженням на підприємстві [8]:

- комплексність - впровадження засад ресурсозбереження на всіх ланках та у всі процеси підприємства;

- системність - впровадження ресурсозбереження 3 урахуванням взаємозв'язків та взаємодії між керованою та керуючою підсистемами;

- сталість - система ресурсозбереження має діяти на постійній основі;

- вимірюваність - ефективність діяльності системи має визначатися певним набором вимірюваних показників;

- залученість персоналу - весь персонал підприємства має бути залучений до системи управління ресурсозбереженням;

- відкритість - система має керуватися принципом «зсередининазовні», тобто впроваджувати та стимулювати ресурсозбереження не лише на підприємстві, а також в його найближчому зовнішньому середовищі;

- динамічність - здатність системи адаптуватися та змінюватися відповідно до потреб підприємства та зовнішнього середовища.

Управління ресурсозбереженням, як і будь-який інший вид діяльності, вимагає конкретної оцінки, визначення його ефективності. Проте політика ресурсозбереження на вітчизняних промислових підприємствах ще не набула широкого поширення, внаслідок відсутності державно затверджених стандартів та нормативів, які б сприяли розробці методичного інструментарію для оцінки економічних ефектів від впровадження ресурсозберігаючих заходів та стимулювали б ресурсоощадливу діяльність господарюючих суб'єктів [9].

В загальному розумінні під ефектами ресурсозбереження розуміються комплексні ефекти, що поєднують економічну, соціальну та екологічну складові. Проте, у контексті стимулювання підприємств до впровадження ресурсозберігаючих заходів доцільно розглядати всі ці складові саме через призму економічної ефективності, адже перш за все важливим рушійним фактором та своєрідним стимулом прийняття рішення щодо впровадження ресурсозбереження на підприємстві є їх економічна доцільність. 
Процеси ресурсозбереження на підприємстві позитивно впливають на широке коло суб'єктів, що сприймають його результати. До них можна віднести: підприємство-виконавця ресурсозберігаючих заходів, споживачів його продукції, торговельних партнерів, працівників підприємства. Для кожного суб'єкта ефект від ресурсозбереження полягає в покращенні умов діяльності, збільшенні його доходів та покращенні якості продукції (рис.1).

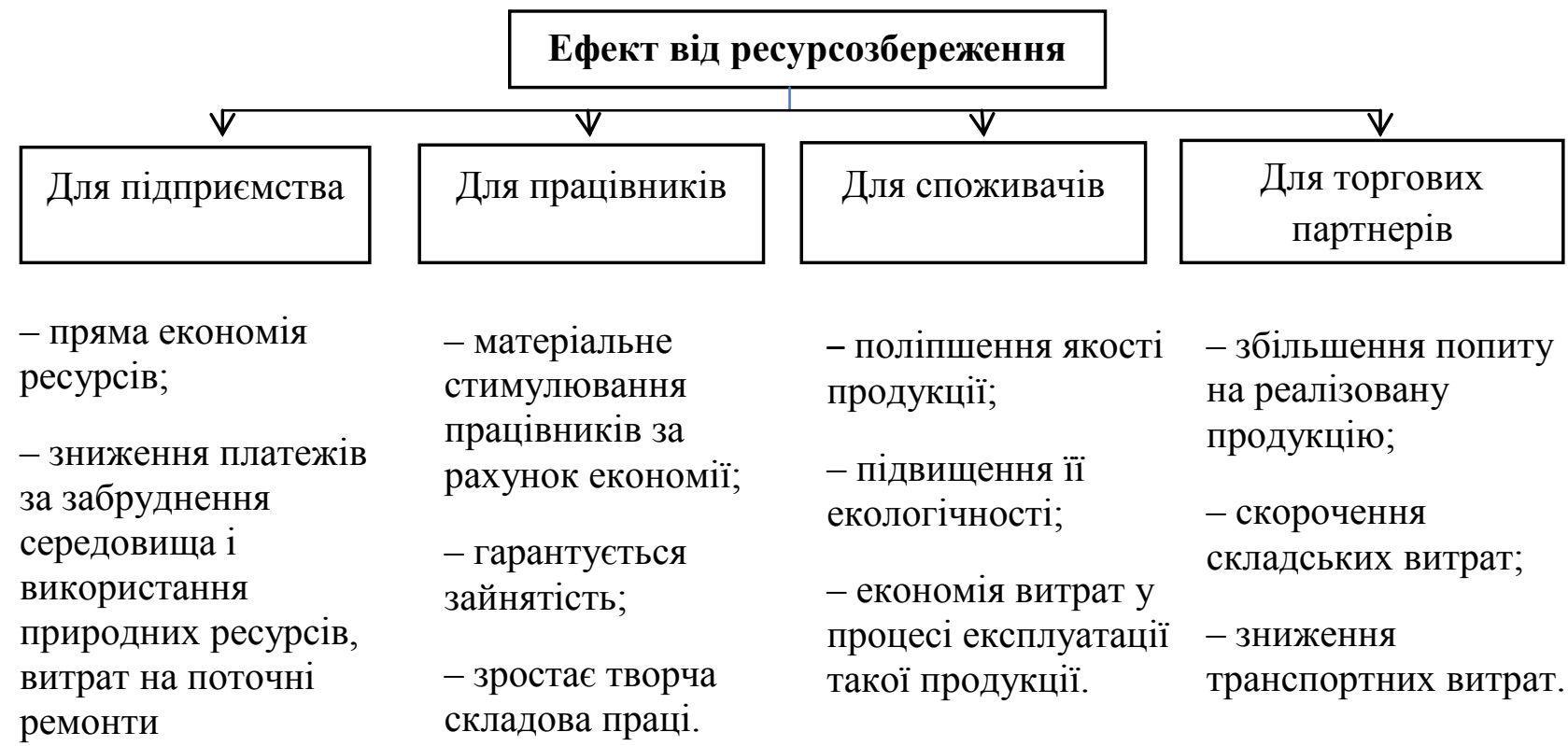

устаткування;

- зростання обсягів

реалізації продукції за

рахунок підвищення іiі

якості;

- зростання вартості

нематеріальних

активів підприємства.

Рис. 1. Ефект від ресурсозбереження

Джерело: [9]

Сьогодні визначальний вплив на розвиток економічної ситуації в Україні справляє енергетичний фактор. Енергетична залежність змушує керівників впроваджувати енергоефективні технології, енергозберігаючі проекти. Прикладом для проведення діагностики стратегічного управління та оцінки впроваджених на сьогодні заходів ресурсозбереження слугувало вітчизняне пивоварне підприємство ПАТ «Оболонь».

Стратегія корпорації «Оболонь» націлена в першу чергу на задоволення вимог та очікувань замовників i, за рахунок цього, на утримання лідируючої позиції на ринку пива та безалкогольних напоїв, при постійній увазі до збереження навколишнього середовища та врахуванні інтересів усіх 
зацікавлених сторін. В останні роки реалізовано значні інвестиційні проекти, спрямовані на зменшення впливу на довкілля - збір та переробка ПЕТ пляшки, переробка сирої пивної дробини на корм для потреби сільського господарства, зменшення шкідливих викидів в атмосферу та забезпечення ощадливого використання ресурсів. Це дозволяє значно знизити вплив на природу, а також підвищити еко-свідомість та еко-культуру працівників[10].

Задля підвищення ефективності діяльності ПАТ «Оболонь» та завоювання переваг у конкурентній боротьбі, ми розглянули закордонний досвід стратегічного управління ресурсозбереженням на підприємствах пивоварної галузі [2].

Для України великий потенціал мають відновлювані джерела енергії, проте, як і раніше, вони практично не використовуються. Експерти відзначають ряд негативних чинників, які гальмують розвиток альтернативної енергетики в нашій країні. Головними 3 них є: застарілі мережі розподілу енергіі; бюрократичні складності оформлення дозвільних документів та реєстрації прав власності на землю; економічна відсталість регіонів, де будівництво енергетичних потужностей $є$ найкращим.

Сонячна енергетика відноситься до так званої «зеленої» енергетики, котра, по міркам людства, є невичерпною. Територія України потрапляє в зону середньої інтенсивності сонячної радіації. Однак в нашій країні більше сонячних годин на рік, ніж в більшості країн $\mathrm{CC}$, що робить ії дуже привабливою в плані інвестицій в місцеву геліоенергетику[1].

На закордонних промислових підприємствах активно встановлюються сонячні батареї. Для прикладу, нідерландська пивоварна компанія «Heineken» ставить перед собою мету скоротити викиди вуглекислого газу на $40 \%$ до 2020 року, а тому велика увага приділяється збільшенню використання саме відновлюваних джерел енергії, таких як сонячна та вітрова енергетика [11].

В умовах зростання цін на сировину та електроенергію, враховуючи, що виробництво i упакування пива достатньо енергоємні, для підприємств пивоварної галузі вигідно скорочувати енергоспоживання за рахунок стратегії повторного використання ресурсів та стратегії енергозбереження.

Однією 3 передових систем енергозбереження для пивоварної промисловості $\epsilon$ сучасна система для рекуперації теплової енергії 3 конденсуючого пару - Mycomizer, яка дозволяє повторно використовувати теплову енергію із сусловарильного котла, потребує менше очищення теплообмінника сусла, скорочує викиди охолодженого конденсату в атмосферу.

Запропонований проект для ПАТ «Оболонь» розрахований на 4 роки, а його загальна вартість становить 10000000 грн. Ця сума може бути повністю виділена із чистого прибутку підприємства, зважаючи на те, що середньорічний прибуток ПАТ «Оболонь» у 2013-2015 роках становив в 
середньому 200000 млн. грн. Проведені розрахунки вказують, що проект доцільно прийняти, адже навіть у мовах високої інфляції значення NPV $\epsilon$ позитивним і складає 12461 601грн,період покриття інвестицій займає менше чотирьох років (а саме 3 роки і 3 місяці), а показник рентабельності (індекс прибутковості) $=1,3(\mathrm{PI}>1)$.

Іншими стратегіями, які може взяти до розгляду у ході своєї діяльності ПАТ «Оболонь» є стратегії раціонального використання води, енергії та утилізації.

У більшості країн Свропейського Союзу використовується раціональна система сортування відходів на пивоварнях - використовуються 2 типи сміттєвих ємностей для збору відходів виробництва: в ємність зеленого кольору складують сміття, яке підлягає традиційній утилізації, а в ємність жовтого кольору - усі види тароупаковок (пластикова тара, металічна упаковка, картон і т.д.). На окремих підприємствах окремо складується i склотара - це ефективний спосіб вторинного використання пляшок, що зменшує собівартість продукції на 50\%. Подібна технологія є ефективною не тільки на промислових підприємствах, а й серед населення, однак одночасно іiі реалізація потребує формування у населення відповідної мотивації, а також створення відповідної інфраструктури для роздільного збору відходів та їх подальшої переробки [11].

Висновки. 3 кожним роком зростає кількість підприємств, які починають поступово впроваджувати ресурсозберігаючі технології. Зважаючи на дефіцит власних ресурсів, високі ціни на паливо та електроенергію, це виступає чи не єдиною можливістю забезпечувати конкурентоспроможність та втримувати позиції на ринку.

Наукова новизна дослідження полягає у систематизації теоретикоприкладних засад реалізації політики ресурсозбереження підприємства, удосконаленні системи енергозбереження на підприємствах пивоварної галузі, подальшому розвитку питань стратегічного управління ресурсозбереженням в харчовій промисловості в умовах енергетичних обмежень при використанні вторинних ресурсів та альтернативних джерел енергії.

Теоретичне і практичне значення результатів дослідження полягає в тому, що сформовані та економічно обгрунтовані у роботі рекомендації щодо удосконалення системи енергозбереження можуть бути впровадженні ПАТ «Оболонь», оскільки сприятимуть підвищенню ефективності використання енергоресурсів, дозволять покращити виробничий процес та збільшити прибутковість компанії.

До перспектив подальших наукових розробок слід віднести формування практичного та ефективного інструментарію щодо оцінювання ефективності ресурсозберігаючих заходів на промислових підприємствах, які будуть простими та ефективними в обчисленні. 


\section{Література:}

1. Зеркалов Д.В. Енергозбереження в Україні: монографія/ Д.В. Зеркалов. - К: Основа.2012 - Електронний ресурс. Режим доступу: https://docviewer.yandex.ua/?url=yaserp $\% 3 \mathrm{~A} \% 2 \mathrm{~F} \% 2 \mathrm{Fwww} . z e r k a l o v . o r g \% 2 \mathrm{Ffiles} \% 2 \mathrm{Fevu}-$ zm.pdf\&page $=1 \& \mathrm{c}=55638 \mathrm{e} 8 \mathrm{a} 87 \mathrm{c} 4$

2. Довгань Л. С., Каракай Ю. В., Артеменко Л. П. Стратегічне управління: Навчальний посібник. - К.: Центр учбової літератури, 2011. — 440 с.

3. Сотник М. I., Сотник I. М. Ресурсозберігаючі технології на внутрішньому ринку України: проблеми просування та шляхи ії вирішення / М. І. Сотник, I. М. Сотник // Механізм регулювання економіки. - 2007. - № 4. - С. 191-195.

4. Мельничук Н. В. Оцінка ефективності ресурсозбереження на рівні підприємства [Електронний ресурс] / Мельничук Н. В. - Режим доступу: http://archive.nbuv.gov.ua/portal/Chem_Biol/Vnuvgp/ekon/2011_4/Vek5627.pdf.

5. Куцик В. I, Олійник М. В. Вибір стратегічних напрямів ресурсозбереження на підприєстві. [Електронний ресурс]. - Режим доступу: http://www.rusnauka.com/11_NPE_2013/Economics/10_134032.doc.htm

6. Социально-экономический потенциал устойчивого развития: практикум/ под ред. Л. Г. Мельника, Л. Хенса. - Сумы : ЛТД «Университетская книга». - 2007. - 335 с.

7. Сршова О. О. Ресурсозбереження як альтернативний спосіб господарювання на підприємствах АПК / О. О. Єршова // Електронне наукове фахове видання «Ефективна економіка» - 2013. - Режим доступу: http://www.economy.nayka.com.ua/?op=1\&z=1971

8. Ляшенко I.O. Ресурсозбереження у забезпеченні економічної ефективності діяльності деревообробних підприємств / I.О. Ляшенко // монографія. [Електронний ресурс]. Режим доступу: rada.kpi.ua/files/dissertation/dis_Lyashenko_I.O.doc

9. Суперека С. Роль ресурсозбереження в системі конкурентоспроможності виробничих підприємств / С. Суперека // Економічний простір: збірник наукових праць. - 2008. - № 20/1. - С. 191-199.

10. Офіційний сайт ПАТ «Оболонь». - Режим доступу:http://obolon.ua/ukr/

11. Артеменко Л.П., Мазур О.В. Міжнародний бенчмаркінг стратегій ресурсозбереження промислових підприємств / Електронне наукове фахове видання «Економіка та суспільство», Мукачево: Мукачівський державний університет - №6. - 2016p. 